Lucia MOZOLOVÁ ${ }^{1}, \check{S}^{\prime}$ efan MOZOL ${ }^{2}$

Opiekun naukowy: Patrik GRZNÁR ${ }^{3}$

DOI: https://doi.org/10.53052/9788366249844.14

\title{
METAMODELOWANIE SYMULACYJNE W SYSTEMACH PRODUKCYJNYCH
}

\begin{abstract}
Streszczenie: Trudność symulacji, zwłaszcza w przypadku złożonych systemów, wiąże się z wysokimi wymaganiami obliczeniowymi. W tym obszarze zaczyna się rozwijać technika metamodelowania. Artykuł opisuje, jak wykorzystać metamodelowanie symulacyjne do rozwiązywania wymagających obliczeniowo zadań na konkretnych wybranych opisanych przykładach.
\end{abstract}

Słowa kluczowe: symulacja, metamodelowanie symulacyjne, podejmowanie decyzji, złożone systemy produkcyjne

\section{SIMULATION METAMODELING IN PRODUCTION SYSTEMS}

Summary: The difficulty of simulation, especially for complex systems, are high computational requirements. In this area, the metamodeling techniques are now under constant development. The article describes the use of simulation metamodeling to solve computationally demanding tasks in specific described selected examples.

Keywords: simulation, simulation metamodeling, decision making, complex production systems

\section{Introduction}

Nowadays, simulation technology is experiencing an increase in application in practice. It is applied mainly for dealing with different types of decision-making tasks. With increasing requirements for the production system, simulation becomes

\footnotetext{
${ }^{1}$ Ing., University of Žilina, Faculty of Mechanical Engineering, Department of Industrial Engineering, e-mail: lucia.mozolova@fstroj.uniza.sk

${ }^{2}$ Ing., PhD., University of Žilina, Faculty of Mechanical Engineering, Research and Service center, e-mail: stefan.mozol@fstroj.uniza.sk

${ }^{3}$ doc. Ing., PhD., University of Žilina, Faculty of Mechanical Engineering, Department of Industrial Engineering, e-mail: patrik.grznar@fstroj.uniza.sk
} 
an almost necessary part of decision-making processes. It is possible to verify the proposals for solutions or create new solutions to solve the problem under examination before implementing them themselves. The increasing complexity of production systems caused by the application of new Key Enabling Technologies (KET) increases the number of elements in systems. Routine planning and control lead to less efficient solutions that are not always close to a sub-optimal solution. The simulation application has proven to be an effective tool for solving these problems. In simulations, the rule is that in terms of computational difficulty, the more factors and the higher the accuracy of the simulation we require, the more timeconsuming it is to obtain the resulting solution. In particular, in terms of computational complexity, more complex systems are demanding than conventional simulations of models with low autonomy. If the automatic system implements the decision by simulation, this decision must be made as quickly as possible. Therefore, metamodels are applied to solve computational tasks where the requirement for quick decisionmaking within autonomous elements is applied. Metamodeling provides a quick and efficient solution to certain tasks depending on a specific type of output. The metamodel is represented by a function whose output is determined by input variables. The metamodel is represented by a function whose output is determined by input variables. They are therefore an ideal choice for control systems based on multiagent control. The article itself deals with the evaluation of current knowledge, terminology and selected works solved in the field and outlines its future application in practice and research.

\subsection{Simulation}

For the definition of simulation, it is necessary to clarify the concept of modelling first. It is an activity that involves taking the characteristics of a real system created by a simulation model so that this model can be further explored. This activity includes the creation and testing of a simulation model. The simulation model is similar between the modelled system (original) and the modelling system. According to specific criteria, it is an experimental information process where a different system is assigned under examination. It is a replacement of the original system with its model. [1] Simulation is one of the experimental statistical methods. It is essentially a substitute for the system under examination (the model's original real system). With this model, a series of experiments are carried out to design the optimisation of the system being studied. According to [1], this method comes with several advantages:

- Identification of bottlenecks risks.

- Determination of maximum production throughput.

- Determination of the appropriate production/transport batch.

- Avoidance of incorrect decisions in the design and preparatory phase of the project.

- Determination of the use of equipment and production /logistics personnel.

- Determination of the maximum size of warehouses.

- Dynamic verification of several variants of the proposed solution for its implementation.

On the other hand, however, the simulation is also associated with certain disadvantages in the form of high costs for the analysis itself, respectively 
the formulation of the objective, the limitation of the problem and the plan of experiments. The increased costs are not only in financial but also in time form. These also concern the design of the model, the implementation of the simulation experiments themselves, as well as the creation of documentation. [2] Simulation is a method available to everyone today. Modern simulation systems use virtual reality, for example. Even the latest simulation systems allow you to simulate the behaviour of complex systems using agent simulation. One of the new technologies used to design and test production systems is a digital twin or even a symbiotic simulation. However, managing complex systems is still a complex and demanding process. Therefore, ways are being sought to simplify it. One option is to use simulation metamodelisation. It is mainly used in the management of continuous systems, while there are still very few practical applications for managing discrete systems. [3]

\subsection{Simulation metamodels}

The analysis of real systems is a very demanding and often costly process. Even in cases where a given system does not exist (conceptual system), analysis cannot be performed. It could even result in the failure of the system analysed. Simulation is a method that can simplify this analysis and make it significantly cheaper. Although in cases where a very precise and valid model is needed, and the modelled system is very complex for computational difficulty, simulation is not a simple and inexpensive method. Nor does the simulation provide a direct explanation for the behaviour of the observed system. The outputs provided by the simulation are valid only for given input conditions, so further simulation is required to verify other conditions values. In such cases, it is necessary to use another method that can approximate the outputs of the simulation model. It's simulation metamodeling.

Simulation metamodeling approximates the Input/Output behaviour of the simulation model. The advantages of simulation metamodeling are that the metamodel has an explicit form, provides a deterministic approach, and the metamodel is computationally unpretentious. This method more easily describes and explains reality. It is suitable for quick decision-making. Basically, it is about modelling a simulation model that is represented by its output data. Because another model is being worked on, it is referred to as a metamodel. Metamodels are used to study the behaviour of computer simulations. Their aim is to contextual the output data of the simulation model to the model inputs to support the purpose for which the simulation model was developed. Basically explains the basic Input/Output relationships of the system through simple mathematical functions see (Figure 1). [4]

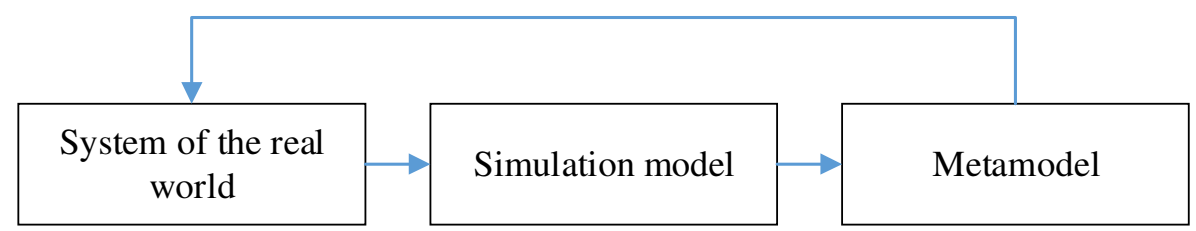

Figure 1. The relationship in metamodeling [4]

According to [4], the most commonly used metamodel techniques are based on parametric polynomial approximation of outputs. For the compilation of metamodels, there are different techniques: 
- Linear polynomial approximations.

- Non-linear approaches, which include e.g.: nonlinear regression, Kriging and Neural networks.

- Other techniques (e.g. rational metamodels, radial function bases, Bayesian approaches).

\subsection{Neural networks}

Artificial neural networks (ANN) are information processing systems with specific performance characteristics in common with biological neural networks (NN). ANN mimics the ability of biological nervous systems to perform complex tasks in decision-making processes without prior programming. [5] ANN was developed as generalising mathematical models of human behaviour or neural biology, based on assumptions:

- Information processing occurs in many simple elements called neurons.

- $\quad$ Signals pass between neurons connected by bindings.

- Each connecting binding has an associated weight, which in typical NN multiplies the signal transmission.

- $\quad$ Each neuron uses an activation function (usually nonlinear) for network outputs (amount of input signal scales) to determine the output signal.

$\mathrm{NN}$ is characterised by its pattern of connections between neurons (called architecture), its method of determining the balance in connections (called training, learning, algorithm), and its activation function. NN consists of a large number of simple processing elements called neurons, drives, cells or nodes. Each neuron is associated with additional neurons using controlled communication links, each with an associated scale. Scales represent the information used by the network to solve the problem. NN can be applied to various problems, such as storing or eliciting data or patterns, classifying patterns, performing general mappings from input patterns to output patterns, hailing similar patterns, or finding a solution for limited optimisation problems.

ANN, compared to traditional techniques, require fewer prerequisites and less accurate information about the modelled system. ANN are networks of numeric processors. Their inputs and outputs are combined according to specific topologies. In general, ANN is a technique for calculating metamodel coefficients and predicted values. A significant feature of ANN is that it can be described as a universal function approximation. Learning is an essential attribute of ANN, which distinguishes them from classic PC use. [7]

According to [7], applications of ANN are in the task:

- Classification or association tasks.

- Prediction tasks.

- Generational tasks.

- Problems of data approximation.

- Problems of process control.

- Transformation of signals.

- Association problems.

- Memory simulation. 


\section{Current application of simulation metamodeling}

Simulation and simulation metamodels are represented by methods for acquiring and expanding knowledge of the proposed or improved system. Based on these, it is possible to implement decisions that result in optimising the production system's selected parameters see (Figure 2). [8]

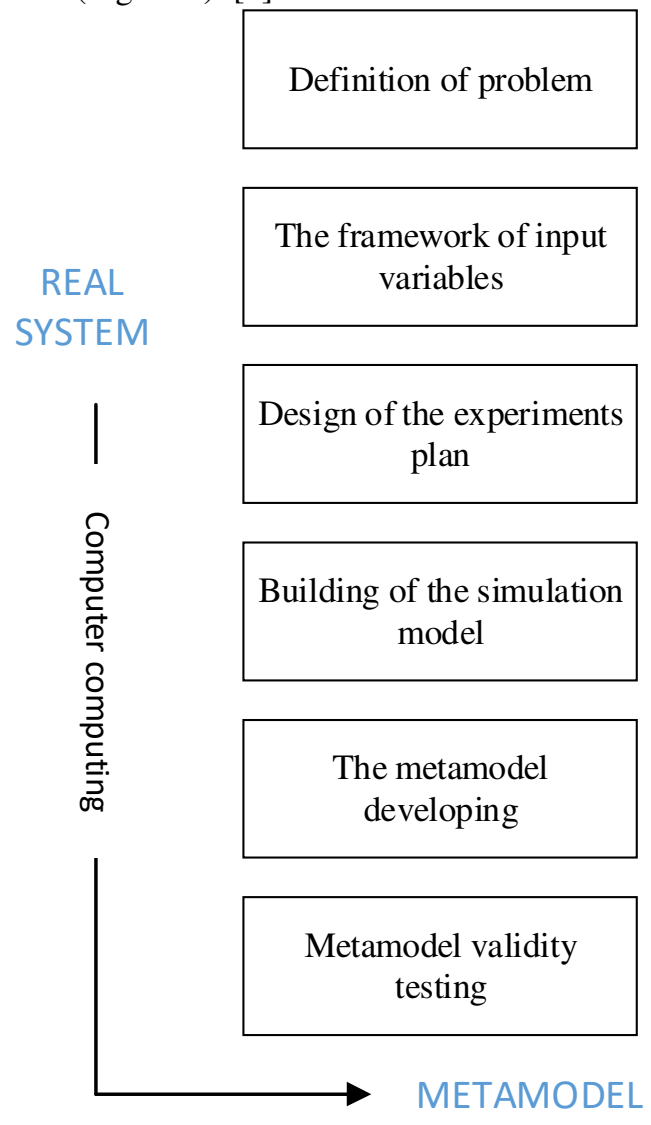

Figure 2. Steps of metamodel development [8]

In the field of metamodeling, several works have been published. In the following section of the chapter, which will be described in selected studies by authors [8], [9] and [10] together with their content. In his research, the author [8] deals with the use of metamodeling for a solve manufacturing job shop. It was an assembly production consisting of four machines where parts were transported through AGV. In production, they process three types of parts. A simulation model of this system has been developed. The occupancy rate of machines, bottlenecks as well as underused machines were detected. The architecture corresponding to NN needs an input and an output layer composed of 4 cells. Simulation experiments were carried out. The first series was used as a training kit, and the second was used as a generalisation of the base to test the accuracy of the network. The calculations were carried out with SW retrospective dissemination of NN. It is characterised by 
different architectures - more or less hidden layers with more or less cells and different learning parameters selected empirically. NN's performance was assessed by the number of examples they could recognise. The best results were achieved by NN composed of three hidden layers. A certain number of learning cycles have been implemented. Their number can be reduced with less accuracy and improve the result through more sophisticated learning algorithms. This example has shown that it is possible to develop an $\mathrm{NN}$ metamodel with a small number of hidden cells, modelled by a simulation model with acceptable accuracy, to be used in practice. The accuracy achieved is sufficient for NN to predict bottlenecks and insufficient use of machines without simulation experiments. Such information could significantly contribute to the development of dynamic job shop planning strategies that could be integrated into the knowledge-based system.

The author [9] dealt with the simulation of production systems and emulation as an advanced approach to simulating production and logistics processes. It focused on metamodel as one of the main ways to increase the efficiency of simulation optimisation and how to reduce the requirements for time-consuming simulation of production systems. She described the basics of metamodeling on specific examples and described NN metamodel as a universal function approximation. In her research, she described the basics of metamodeling. It stated how to create a metamodel based on the simulation model of the production cell in the Zilina Intelligent Manufacturing System (ZIMS) concept, which consists of three machines (successive machining). The aim was to design a metamodel for the average time that changes due to changes in factor levels. The metamodel validation was carried out by comparing the outputs of the metamodel with the output data of the simulation using mathematical statistics. In this case, a regression model with poly-level polynomials was used. Based on statistics, stage III polynomial was selected. The collected data approximator can be implemented using ANN. These can be designed and trained to perform regression. Their generalisation capacity should ensure that the results for still invisible data points are approximately the same.

If a set of input values is provided, the simulation shall provide the corresponding output values. These Input/Output pairs were used to compile the data file. The data set was divided into two parts - the training data set and the validation data set. Several learning algorithms were tested, based on which it was chosen most appropriately. One of the known drawbacks of ANN is the lack of a comprehensive method of selecting the most appropriate architecture for a given task. Therefore, the usual approach is to use the trial-error method to find the exemplary architecture. The architecture was chosen, in which the best results were achieved. Based on validation, it has been verified that the network can be used to estimate outputs with specific expected errors.

The last of the defined authors [10] dealt with metamodelisation as a practical approach to the statistical summation of simulation results. He gave a practical example of how metamodel can be developed and verified using simple CONWIP production systems. Various types of production systems (Kanban, CONWIP, Drum Buffer Rope - DBR, Load Oriented Control - LOC and Material Requirements Planning - MRP) have been tested. Their analysis focused on the effects of the number of CONWIP cards on defined parameters (production, performance, work in development, production time). They made the analysis more accessible by tracking the relationship of one factor (CONWIP card count) to one output parameter 
(average production time). They described their relationship using regression analysis. The grade $\mathrm{V}$ polynomial equation provided the best results. A predefined value gives you the ability to find out the average production time for a given number of CONWIP cards very quickly and without using simulation. However, there was a problem using a value above the interval used to develop the metamodel. If more CONWIP cards were considered, there would be a significant difference between the average time from the calculation and the simulation. For such values, it is not appropriate to use the polynomial equation of a given $\mathrm{V}$. degree to replace the simulation for these values.

\section{Conclusion}

The increase in the complexity of production systems leads to the need to use tools that can reliably predict the outcome of the action. High computational and timeconsuming needs characterise conventional simulation tools designed for dynamic simulation, especially when we solve large systems. In such cases, approximation solutions based on metamodels begin to be applied, allowing for an approximate definition of the outcome of the action in a short time. A significant advantage is a less computational complexity of using such a solution. Current research in this area makes it possible to detect bottlenecks in production, the occupancy rate of machines, and underused machines. In this case, reverse propagation metamodels may be used to detect the above. Such a solution does not make it necessary to use simulation experiments and can also contribute to developing dynamic planning strategies that could be integrated into the knowledge-based system. Furthermore, thanks to metamodels, it is possible to increase the actual efficiency of simulation optimisation and, in particular, reduce the requirements for time-consuming simulation. This can be solved through a regression model using polynomials of different degrees. On these foundations, it is possible to use artificial neural networks as a universal function approximation. However, ANN-based metamodels have a significant disadvantage. The usual approach to finding the appropriate architecture for a given solution is realised by the trial-error method. Ultimately, such a solution can be used to predict the behaviour of the system as well as the outputs of the system itself. Another way of using metamodelisation is as an approach to the statistical summation of simulation results. It can be tested on different production systems. Again, it is possible to use regression analysis using polynomic function. Such a solution allows you to quickly and without simulation find out the average production time.

\section{ACKNOWLEADGMENT}

This article was created with support of VEGA project: VEGA 1/0225/21. 


\section{REFERENCES}

1. MOZOLOVÁ L.: Počítačová simulácia pri zefektívnení montážneho procesu. Žilinská univerzita v Žiline, 2021. 83.

2. MOZOL Š., GRZNÁR P., VAVRÍK V.: MANUFACTURING BUFFERS CAPACITY DIMENSIONING IN A COMPANY. Technologie, procesy i systemy produkcyjne, 2018, 167-176.

3. PLINTA D., GRZNAR P.: Optimisation of production processes with the use of the modelling and simulation method. 14th International Conference on Modern Technologies in Manufacturing (MTeM), 299(2019), Article Number: 03007.

4. PALAJOVÁ S.: Simulačné metamodelovanie výrobných systémov. Žilinská univerzita v Žiline, 2012. 149.

5. MOUELHI W., HUYET A., PIERREVAL H.: COMBINING SIMULATION AND ARTIFICIAL NEURAL NETWORKS: AN OVERVIEW. Proc. EUROSIM 2007, Ljubljana 2007, 11.

6. KVASNIČKA V., BEŇUŠKOVÁ L', POSPÍCHAL J., FARKAŠ I., TIŇO P., KRÁL' A.: Úvod do teórie neurónových sietí. Iris, Bratislava 1997.

7. PIERREVAL H.: A metamodeling approach based on neural networks. International Journal of Computer Simulation, 6(1996), 365-378.

8. GREGOR M., ŠTEFÁNIK A., HROMADA J.: Lean Manufacturing Systems Optimisation Supported by Metamodelling. OAI, (2006), 175-183.

9. GREGOR M., PALAJOVÁ S., GREGOR M.: Simulation Metamodelling of Manufacturing Systems with the Use of Artifcial Neural Networks. 14th International Conference on MITIP - Modern Information Technology in the Innovation Processes of Industrial Enterprises, 14(2012), 178-189.

10. GREGOR M., HALUŠKOVÁ M., HROMADA J., KOŠTURIAK J., MATUSZEK J.: Simulation of Manufacturing Systems. Politechnika Lodzka, 1998, 134. 